\title{
Differences in Coaching Needs Among Underrepresented Minority Medical Students
}

Skender Najibi, MD; Patricia A. Carney, PhD; Erin Thayer, BS; Nicole Deiorio, MD

\begin{abstract}
BACKGROUND AND OBJECTIVES: Little is known about how the academic coaching needs of medical students differ between those who are racially, ethnically, and socially underrepresented minority (RES-URM) and those who represent the majority. This single-site exploratory study investigated student perceptions and coaching needs associated with a mandatory academic coaching program, and coaches' understanding of and preparedness to address these potentially differing needs.
\end{abstract}

METHODS: Coaching needs of second- and third-year medical students were assessed using two initial focus groups and two validation focus groups, one consisting of RES-URM students and the other majority medical students. Coaches were assessed using a cross-sectional self-administered survey designed to determine their perceptions of differing coaching needs of students

RESULTS: Seven themes emerged from the student focus groups. Three of these reflected the coaching relationship, and four reflected the coaching process. RES-URM students expressed stress around sharing vulnerability that was not expressed among majority students. Sixty-eight percent of coaches expressed that RES-URM students would not have differing needs of their coaches. Coaches self-rated as being somewhat (45\%), moderately $(29 \%)$, or very $(13 \%)$ skilled at coaching RES-URM students.

CONCLUSIONS: RES-URM students cite different coaching needs than majority students that most coaches do not recognize. Faculty and program development regarding these unique needs is warranted.

(Fam Med. 2019;51(6):516-22.)

doi: 10.22454/FamMed.2019.100305

A pproximately $81 \%$ of medical schools have programs designed to recruit underrepresented minority students to diversify the student body toward serving diverse and underserved populations. ${ }^{1,2}$ As a result, the racial profile of US medical school enrollees has shifted, with $46.9 \%$ identifying themselves as nonwhite in $2016 / 2017 .{ }^{3,4}$ While programs dedicated to matriculation of minority students appear well established, and many medical schools offer prematriculation programs for students with diverse backgrounds, ${ }^{5-8}$ less in known about what is needed to help them succeed once enrolled.

Academic coaching has been used in undergraduate education and elsewhere ${ }^{9-14}$ to enhance performance. Coaching is emerging as a new model to prepare learners in competency-based medical education. ${ }^{9,15}$ In a prior study, we defined academic coaching as a developmental process whereby an individual learner meets regularly over time with a faculty coach to create goals, identify strategies to manage existing and potential challenges, improve academic performance, and develop professional identity toward reaching the learner's highest potential. ${ }^{16}$ Thus, academic coaching, which differs from mentoring and advising in that it is learner driven and emphasizes individualized goals, could meet minority medical students' needs in particular. ${ }^{14,16-18}$

In this mixed-methods study, we examined how perspectives and coaching needs of medical students differ between RES-URM and majority medical students, and assessed coaches' awareness of potential differences among these student groups.

\section{Methods}

Oregon Health \& Science University's (OHSU's) mandatory coaching program is comprised of clinicianeducator MD coaches, who receive regular faculty development and are assigned to all medical students.

From Contra Costa Regional Medical Center, Martinez, CA (Dr Najibi), and Oregon Health \& Science University, Portland, OR (Drs Carney and Deiorio, and Ms Thayer). 
Coaching meetings occur every 6 weeks, where student's e-portfolios are reviewed, academic goals are created, and approaches for meeting goals are discussed. Students also meet with their coach in small groups to explore professional identity topics.

OHSU's Institutional Review Board reviewed and approved all study activities (IRB\# 16147). For focus groups, all second- and thirdyear medical students in the graduating classes of 2018 and 2019 were invited $(n=280)$. Targeted recruitment for URM students was done with the assistance of the Center for Diversity and Inclusion's Student Interest Groups and the student council. The first 20 who responded (10 in the URM group and 10 in the non-URM group) were enrolled. RES-URM were defined as members of racial, ethnic, or socioeconomic groups, including diversity in economic, sexual orientation, or disability status that are underrepresented in medicine relative to local and national demographics. ${ }^{19}$ Four focus groups were held, two initial sessions, one each with RES-URM and majority students, both of which addressed questions included in Table 1, and were facilitated by an experienced investigator. After initial qualitative data analyses were complete, validation focus groups were held with each group to share findings and assess reactions.
All faculty coaches from OHSU's coaching program $(n=33)$ were invited to complete an 11-item online deidentified survey that was pilot tested, ${ }^{20}$ then administered in November 2016.

\section{Data Analysis}

Analyses of focus group data involved open and axial coding of field notes by two independent investigators using constant comparative analyses and immersion crystallization techniques. ${ }^{21,22}$ Emergent themes were identified and defined, and exemplars selected using consensus meetings. Findings were presented at the validation focus groups and only minor revisions were applied. Descriptive statistics were used to characterize coaches' survey responses.

\section{Results \\ Medical Student Results}

Focus group participants' demographics are summarized in Table 2 . Seven themes emerged from the focus groups: three regarding the coaching relationship, and four centering on coaching processes (Table 3). Regarding the relationship, RES-URM students voiced tension around coaches not overly focusing on race while also not ignoring it. RES-URM students perceive they experience greater pressure to succeed because they are the school's face of diversity. RES-URM students indicated it was less important to have a coach identify as RES-URM than to have a coach who understands the importance of culture and how it might affect the coaching relationship and processes.

Regarding the process, while majority students perceived that sharing vulnerabilities would help them learn more about themselves, RES-URM students reported sharing vulnerabilities is very stressful for them (Table 3). RES-URM students preferred to have set guidelines about the coaching relationship and processes to help them decide how to handle their vulnerabilities and related stressors.

\section{Coaches Results}

Thirty-one of 33 (93.9\%) coaches completed the survey (Table 4). Seven $(22.6 \%)$ self-identified as RES-URM, a number too small for meaningful comparisons. Twenty-one coaches (67.7\%) perceived that RES-URM students would not have different needs than majority students. When asked to rate their skill in coaching RES-URMs, many $(45.2 \%)$ reported being somewhat skilled. Only $4(12.9 \%)$ reported being very skilled. Most (67.7\%) reported being very/extremely likely to participate in programs to help address RES-URM medical students' needs.

Table 1: Focus Group Questions for Medical Student Participants

\begin{tabular}{|c|l|}
\hline Question \# & \multicolumn{1}{c|}{ Questions and Planned Probes } \\
\hline 1 & $\begin{array}{l}\text { Tell us about your experiences with the coaching program. } \\
\text { Probe: What do you want from your coach? } \\
\text { Probe: At this point in medical school, what do you want your coach to know? about you }\end{array}$ \\
\hline 2 & $\begin{array}{l}\text { Have you heard about coaches you wish you had? } \\
\text { Probe: Why? }\end{array}$ \\
\hline 3 & What do you think is the best way to match coaches and medical students? \\
\hline 4 & How important is it to you to identify with your coach? \\
\hline 5 & What do you think are the most important characteristics of your coach? \\
\hline 6 & How have you talked with your coach about any vulnerabilities you may have? \\
\hline 7 & How did your coach respond when you brought your vulnerabilities up? \\
\hline 8 & $\begin{array}{l}\text { How has the coaching experience affected you in terms of feeling a part of } \\
\text { OHSU community? }\end{array}$ \\
\hline
\end{tabular}


Table 2: Focus Group Participants at Focus Groups Sessions Completion

\begin{tabular}{|c|c|c|c|}
\hline Student Characteristics & $\begin{array}{c}\text { Underrepresented } \\
\text { Minority (n=8) } \\
\mathbf{n}(\%)\end{array}$ & $\begin{array}{c}\text { Non-Underrepresented Minority (n=7) } \\
\mathbf{n}(\%)\end{array}$ & Total (n=15) \\
\hline Sex & $1(12.5 \%)$ & $4(57.1 \%)$ & 5 \\
\hline Male & $7(87.5 \%)$ & $3(42.9 \%)$ & 10 \\
\hline Female & $5(62.5 \%)$ & & 7 \\
\hline Educational Program Year & $3(37.5 \%)$ & $5(28.6 \%)$ & 8 \\
\hline 2 & & $5(71.4 \%)$ & \\
\hline 3 & & & \\
\hline
\end{tabular}

Table 3: Differences in RES-URM and Non-RES-URM Perceptions of Coaching Relationships and Coaching Processes

\begin{tabular}{|c|c|c|}
\hline $\begin{array}{l}\text { Emergent Themes That Differ } \\
\text { in the Coaching Relationship }\end{array}$ & Underrepresented Minority Medical Students & $\begin{array}{l}\text { Non-Underrepresented Minority } \\
\text { Medical Students }\end{array}$ \\
\hline $\begin{array}{l}\text { Variability in coaching } \\
\text { (defined as inconsistent } \\
\text { processes for guidance/ } \\
\text { support) }\end{array}$ & $\begin{array}{l}\text { - These students perceive that coaches of } \\
\text { color coach differently compared to white } \\
\text { coaches. They believe white coaches } \\
\text { selectively choose not to talk about race. } \\
\text { - These students indicate a tension exists } \\
\text { between ignoring color/race/ethnicity and } \\
\text { overfocusing on it. They are unsure about } \\
\text { what the right balance is, but this should } \\
\text { be worked about between individual } \\
\text { students and their coaches. }\end{array}$ & $\begin{array}{l}\text { - These students are most concerned } \\
\text { about coaches being responsive to their } \\
\text { questions and perceive that students } \\
\text { and coaches making important } \\
\text { connections varies greatly. } \\
\text { - In some cases, these students feel they } \\
\text { and their coaches are not on the same } \\
\text { page, but these differences are not } \\
\text { related to race, ethnicity or sexual } \\
\text { identity. }\end{array}$ \\
\hline $\begin{array}{l}\text { Relevance of the coach/ } \\
\text { student identity (defined } \\
\text { as the importance of } \\
\text { uniqueness of students) }\end{array}$ & $\begin{array}{l}\text { - These students perceive that culture is } \\
\text { part of being the best medical student } \\
\text { they can be. } \\
\text { - Some feel that family is critically } \\
\text { important to their identity as both } \\
\text { individuals and medical students. } \\
\text { - These students perceive that part of what } \\
\text { makes them good medical students } \\
\text { is their diverse experiences - their } \\
\text { culture allows them to offer different } \\
\text { perspectives. } \\
\text { These students perceive that students of } \\
\text { color and those with different sexual } \\
\text { orientation carry a burden of not being } \\
\text { able to fully "be who they are." } \\
\text { These students experience added pressure } \\
\text { to perform due to the University's } \\
\text { diversity campaign (eg, their presence } \\
\text { on the OHSU web-site predominates) } \\
\text { because they are more recognizable. This } \\
\text { creates significant stress among these } \\
\text { students. } \\
\text { The lack of people of color in Portland, } \\
\text { Oregon is difficult for these students- } \\
\text { they don't see many people like } \\
\text { themselves. }\end{array}$ & $\begin{array}{l}\text { - These students want to be the best } \\
\text { medical students they can be-and they } \\
\text { want their coaches to help them with } \\
\text { this. } \\
\text { - These students do not perceive that } \\
\text { culture, race, or ethnicity is an issue or } \\
\text { an added pressure that will influence } \\
\text { their abilities to succeed. }\end{array}$ \\
\hline
\end{tabular}


Table 3, Continued

\begin{tabular}{|c|c|c|}
\hline $\begin{array}{l}\text { Emergent Themes That Differ } \\
\text { in the Coaching Relationship }\end{array}$ & Underrepresented Minority Medical Students & $\begin{array}{l}\text { Non-Underrepresented Minority } \\
\text { Medical Students }\end{array}$ \\
\hline $\begin{array}{l}\text { Matching of coaches and } \\
\text { students (defined as the } \\
\text { pairing of coaches with } \\
\text { students) }\end{array}$ & $\begin{array}{l}\text { - These students perceive that while } \\
\text { matching according to color can } \\
\text { be helpful ("I will talk differently } \\
\text { with a coach of color"), it is not } \\
\text { necessary, as long as communication } \\
\text { and understanding of race, color, } \\
\text { sexual identity occurs as part of the } \\
\text { development of the coaching relationship. } \\
\text { - These students don't want race to be like } \\
\text { checking a "box"--Ok that is dealt with } \\
\text { because we matched a brown skinned } \\
\text { person with a brown skinned person." } \\
\text { These students voice a strong desire that } \\
\text { coaches understand what they are going } \\
\text { through as RES-URMs. Currently this is } \\
\text { not occurring. }\end{array}$ & $\begin{array}{l}\text { - These students perceive that matching } \\
\text { according to personality may be } \\
\text { more important than matching to } \\
\text { professional discipline. } \\
\text { - These students suggest having } \\
\text { specialized coaches for different tasks } \\
\text { (ie, baseball analogy-batting, pitching, } \\
\text { etc coach), as they perceive their } \\
\text { coaching needs will change over time } \\
\text { and they are not certain a single coach } \\
\text { can serve in all the roles they think } \\
\text { they might need. }\end{array}$ \\
\hline $\begin{array}{l}\text { Characteristics of a } \\
\text { successful coach (defined } \\
\text { as features that result } \\
\text { in effectiveness of the } \\
\text { coaching relationship) }\end{array}$ & $\begin{array}{l}\text { - These students want coaches to } \\
\text { understand them as individuals as well } \\
\text { as medical students. They (students) } \\
\text { would choose for themselves how much } \\
\text { to reveal about their personal lives, as } \\
\text { this is not perceived as necessary to the } \\
\text { coaching process. } \\
\text { - These students want individualized } \\
\text { coaching tailored to their specific needs } \\
\text { and want flexibility as well. }\end{array}$ & $\begin{array}{l}\text { - These students want their coaches to be } \\
\text { adaptable, flexible, and responsive to } \\
\text { their questions/concerns. } \\
\text { - They do not mention wanting anything } \\
\text { beyond success in medical school. }\end{array}$ \\
\hline $\begin{array}{l}\text { Desires from the coaching } \\
\text { process (defined as wishes } \\
\text { or requests students have } \\
\text { for the coaching program) }\end{array}$ & $\begin{array}{l}\text { - These students want help with goals and } \\
\text { clarity regarding what the coaching } \\
\text { process is, what action steps to take and } \\
\text { to be up front about what they should be } \\
\text { doing. } \\
\text { - These students are not looking for a, "Oh } \\
\text { you'll figure it out" reaction from their } \\
\text { coach-this is perceived as not helpful. }\end{array}$ & $\begin{array}{l}\text { - These students want help navigating the } \\
\text { curriculum and special projects, and } \\
\text { they want validation that their goals } \\
\text { mean something. } \\
\text { - These students want specifics on what } \\
\text { to do better, and they are not looking } \\
\text { for "You will do better next time } \\
\text { responses." }\end{array}$ \\
\hline $\begin{array}{l}\text { Coaching style (defined as } \\
\text { the quality or character of } \\
\text { the coaches approach to } \\
\text { students) }\end{array}$ & $\begin{array}{l}\text { - These students indicate there is a balance } \\
\text { between just getting encouragement and } \\
\text { being offered help with goals and actions. } \\
\text { - These students understand their coaches } \\
\text { are busy. }\end{array}$ & $\begin{array}{l}\text { - These students perceive that a tension } \\
\text { exists between having a hands off vs } \\
\text { hands on coach. }\end{array}$ \\
\hline $\begin{array}{l}\text { Expressing/sharing } \\
\text { vulnerabilities (defined as } \\
\text { articulating or revealing } \\
\text { perceived susceptibilities) }\end{array}$ & $\begin{array}{l}\text { - This is very challenging and stressful for } \\
\text { these students. For some members their } \\
\text { identity as RES-URM is obvious-such } \\
\text { as skin color, but for others it is not. } \\
\text { - Among those where this is not obvious, } \\
\text { such as sexual orientation, these } \\
\text { students report a great deal of } \\
\text { stress related to not being able to be } \\
\text { themselves. } \\
\text { - These students desire set guidelines } \\
\text { for what a coach is and what they are } \\
\text { supposed to do, so that they are clearer } \\
\text { about giving feedback about handling } \\
\text { vulnerabilities. }\end{array}$ & $\begin{array}{l}\text { - These students perceive it is valuable to } \\
\text { share vulnerabilities because they will } \\
\text { learn more about themselves. } \\
\text { - These students expect to hear } \\
\text { reassurance and advising on where } \\
\text { to go and they are clear that their } \\
\text { coach is not a counselor; however, they } \\
\text { perceive their coaches as needing to } \\
\text { be. supportive in a similar way. They } \\
\text { understand that coaching isn't a } \\
\text { psychotherapy session. } \\
\text { - These students indicate that feeling like } \\
\text { they are part of the OHSU community } \\
\text { is not important to them. }\end{array}$ \\
\hline
\end{tabular}


Table 4: Faculty Coaches' Survey Responses ( $\mathrm{N}=31$ )

\begin{tabular}{|c|c|c|}
\hline Coach Responses & Average (SD') & Range \\
\hline Mean age in years & $42.0(10.2)$ & $31-64$ \\
\hline Number of Years Coaching & $\mathbf{n}$ & $\%$ \\
\hline 1 & 23 & $74.2 \%$ \\
\hline 2 & 8 & $25.8 \%$ \\
\hline \multicolumn{3}{|l|}{ Gender } \\
\hline Male & 16 & $51.6 \%$ \\
\hline Female & 15 & $48.4 \%$ \\
\hline \multicolumn{3}{|l|}{ Self-identify as Underrepresented Minority* } \\
\hline Yes & 7 & $22.6 \%$ \\
\hline No & 24 & $77.4 \%$ \\
\hline \multicolumn{3}{|c|}{ Perceive That Any Students They Are Coaching Identify Themselves as Members of an Underrepresented Minority } \\
\hline Yes & 23 & $74.2 \%$ \\
\hline No & 7 & $22.6 \%$ \\
\hline Prefer not to answer & 1 & $3.2 \%$ \\
\hline \multicolumn{3}{|l|}{ If Yes, How Did Coach Make This Determination: } \\
\hline Made an assumption, based on appearance & 2 & $8.7 \%$ \\
\hline Conversations with student provided an informal indication & 11 & $47.8 \%$ \\
\hline Student identified themselves in a formal way & 6 & $26.1 \%$ \\
\hline Two or more of the above & 5 & $21.7 \%$ \\
\hline \multicolumn{3}{|c|}{$\begin{array}{l}\text { If Coach Does Not Think Any Students They Are Coaching Identify Themselves as Members of an } \\
\text { Underrepresented Minority, Did They Think the Following Were Useful Ways to Understand Their Status: }\end{array}$} \\
\hline Encourage more openness about self-identity as part of becoming a physician & 2 & $28.6 \%$ \\
\hline $\begin{array}{l}\text { Use a more structured approach to questioning them early in the coaching relationship to } \\
\text { specifically identify this }\end{array}$ & 2 & $28.6 \%$ \\
\hline Prefer not to answer & 1 & $14.3 \%$ \\
\hline Other & 2 & $28.6 \%$ \\
\hline \multicolumn{3}{|l|}{$\begin{array}{l}\text { Do Students Who Identify Themselves as Members of an Underrepresented } \\
\text { Minority Have Different Expectations From Their Coach? }\end{array}$} \\
\hline Yes & 4 & $12.9 \%$ \\
\hline No & 21 & $67.7 \%$ \\
\hline Prefer not to answer & 6 & $19.4 \%$ \\
\hline \multicolumn{3}{|l|}{ If Yes, What Different Needs Do You Think They Have: } \\
\hline Advocacy against institutional and systemic bias & 3 & $75.0 \%$ \\
\hline $\begin{array}{l}\text { Guidance on how to navigate the field, careers with their identity consideration, as well as } \\
\text { support and listening on their thoughts about how they are considered differently or areas } \\
\text { of possible disparity. }\end{array}$ & 1 & $25.0 \%$ \\
\hline \multicolumn{3}{|l|}{$\begin{array}{l}\text { Coaches' Self-rating of Skill Level for Coaching Medical Students Who Identify } \\
\text { Themselves as Members of an Underrepresented Minority Group: }\end{array}$} \\
\hline Not sure & 2 & $6.3 \%$ \\
\hline Not at all skilled & 1 & $3.2 \%$ \\
\hline Somewhat skilled & 14 & $45.2 \%$ \\
\hline Moderately skilled & 9 & $29.0 \%$ \\
\hline Very skilled & 4 & $12.9 \%$ \\
\hline Prefer not to answer & 1 & $3.2 \%$ \\
\hline
\end{tabular}


Table 4, Continued

\begin{tabular}{|l|c|c|}
\hline \multicolumn{1}{|c|}{$\begin{array}{c}\text { If We Designed a Program to Help Address These Needs, } \\
\text { How Likely Would You Be to Take Part in It: }\end{array}$} & Average (SD') & Range \\
\hline Somewhat likely & 4 & $12.9 \%$ \\
\hline Moderately likely & 5 & $16.1 \%$ \\
\hline Very likely & 9 & $29.0 \%$ \\
\hline Extremely likely & 12 & $38.7 \%$ \\
\hline Prefer not to answer & 1 & $3.2 \%$ \\
\hline
\end{tabular}

$\dagger$ Standard deviation

* Defined as a member of a racial or ethnic group, or of socioeconomic, sexual orientation, or disability status that is/are underrepresented in medicine relative to local and national demographics.

\section{Discussion}

Several novel findings emerged from this exploratory research. Recent studies on improving RES-URM medical student performance focus only on academic outcomes, with none aimed at improving the learning environment experienced by RES-URM students. ${ }^{23}$ We found that RES-URM students desire more environmental context to academic coaching and desire a coach who acknowledges the context of a student's culture in their academic achievement. Majority students did not report culture, race, ethnicity, or sexual orientation as barriers to the coaching relationship and processes, in contrast to RES-URM students. Sharing vulnerabilities was very stressful for RES-URMs. As coaching programs are designed to examine students' gaps and areas for improvement, this perception may undermine the primary goal of coaching. In addition, we are concerned with how differences in URM/non-URM affect the process of professional identity formation-an area ripe for future research.

Also striking is the finding that coaches perceive that the needs and expectations of RES-URM students are not substantially different from majority students. If coaching program developers share this view, any coaching program could be developmentally flawed. Professional development for educators should include meaningful interactions between them as faculty and social, cultural and structural working environments. ${ }^{24}$, ${ }^{25}$ Such professional development requires self-reflection and vulnerability, which in turn allows modeling of learner vulnerability.24 Creating a safe learning environment is critical. If RES-URM students feel at risk when sharing vulnerabilities, their professional development could be hindered.

Our study was exploratory due to its size and single-site design. Students and faculty who participated may have differing perceptions of academic coaching, which could have affected our findings.

Our study suggests that RESURM medical students have different coaching needs compared to majority students, a fact that was unappreciated by coaches. These findings have implications for UME leaders and coaching and diversity programs, and warrant further investigation into the best way to achieve optimal coaching outcomes.

ACKNOWLEDGMENTS: This work was supported by Dean's Office at Oregon Health \& Science University via an Accelerating Change in Medical Education Grant from the American Medical Association and by the Research Program in Family Medicine.

CORRESPONDING AUTHOR: Address correspondence to Dr Patricia A. Carney, Department of Family Medicine, Oregon Health \& Science University, 3181 SW Sam Jackson Park Rd, Mail Code: FM, Portland, OR 97239. 503-494-9049. carneyp@ohsu.edu.

\section{References}

1. Sokal-Gutierrez K, Ivey SL, Garcia RM, Azzam A. Evaluation of the Program in Medical Education for the Urban Underserved (PRIMEUS) at the UC Berkeley-UCSF Joint Medical Program (JMP): The First 4 Years. Teach Learn Med. 2015;27(2):189-196.

2. Association of American Medical Colleges. Results of the 2015 Medical School Enrollment Survey: April, 2016. https://members.aamc. org/eweb/upload/2015_Enrollment_Report.pdf. Accessed June 2, 2017.

3. Association of American Medical Colleges. Table B-5: Total Enrollment by US Medical School and Race/Ethnicity: 2016-2017. https:// www.aamc.org/download/321540/data/factstableb5.pdf. Accessed June 6, 2017.

4. Association of American Medical Colleges. Medical School Enrollment Shows Diversity Gains: October, 2010. https://www.aamc.org/ newsroom/newsreleases/2010/152932/101013. html. Accessed June 2, 2017.

5. Grumbach K. Commentary: adopting postbaccalaureate premedical programs to enhance physician workforce diversity. Acad Med. 2011;86(2):154-157.

6. Alexander C, Chen E, Grumbach K. How leaky is the health career pipeline? Minority student achievement in college gateway courses. Acad Med. 2009;84(6):797-802.

7. Wilson WA, Henry MK, Ewing G, et al. A prematriculation intervention to improve the adjustment of students to medical school. Teach Learn Med. 2011;23(3):256-262.

8. American Medical Association. AMA Continues Innovative Initiative to Reshape Medical https:/www.ama-assn.org/press-center/pressreleases/ama-continues-innovative-initiativereshape-medical-education. Published April 13, 2013. Accessed September 9, 2017.

9. Knowles MS. The Modern Practice of Adult Education: From Pedagogy to Andragogy. Cambridge: Prentice Hall Regents; 1970.

10. Cummings TG, Worley CG. Coaching and Mentoring (in) Organizational Development and Change. Mason, OH: South-Western Cengage Learning; 2009. 
11. Gawande A. Personal best. The New Yorker. September 26, 2011. http://www.newyorker. com/magazine/2011/10/03/personal-best. Accessed July 11, 2016.

12. Gazelle G, Liebschutz JM, Riess H. Physician burnout: coaching a way out. J Gen Intern Med. 2015;30(4):508-513.

13. Gifford KA, Fall LH. Doctor coach: a deliberate practice approach to teaching and learning clinical skills. Acad Med. 2014;89(2):272-276.

14. Sargeant J, Lockyer J, Mann K, et al. Facilitated reflective performance feedback: developing an evidence- and theory-based model that builds relationship, explores reactions and content, and coaches for performance change (R2C2). Acad Med. 2015;90(12):1698-1706.

15. Williams SN, Thakore BK, McGee R. Providing social support for underrepresented racial and ethnic minority $\mathrm{PhD}$ students in the biomedical sciences: a career coaching model. CBE Life Sci Educ. 2017;16(4):ar64.

16. Deiorio NM, Carney PA, Kahl LE, Bonura EM, Juve AM. Coaching: a new model for academic and career achievement. Med Educ Online. 2016;21(1):33480.
17. Schumacher DJ, Englander R, Carraccio C. Developing the master learner: applying learning theory to the learner, the teacher, and the learning environment. Acad Med. 2013;88(11):1635-1645.

18. Li ST, Paterniti DA, Co JP, West DC. Successful self-directed lifelong learning in medicine: a conceptual model derived from qualitative analysis of a national survey of pediatric residents. Acad Med. 2010;85(7):1229-1236.

19. Page KR, Castillo-Page L, Poll-Hunter N, Garrison G, Wright SM. Assessing the evolving definition of underrepresented minority and its application in academic medicine. Acad Med 2013;88(1):67-72

20. Beatty PC, Willis GB. Research synthesis: the practice of cognitive interviewing. Public Opin Q. 2007;71(2):287-311.

21. Miller WL, Crabtree BF. The Dance of Interpretation. Crabtree BF, Miller WL. Doing qualitative research. 2nd ed. Thousand Oaks, CA: Sage Publications, Inc; 1999:127-143.

22. Cohen DJ, Crabtree BF. Evaluative criteria for qualitative research in health care: controversies and recommendations. Ann Fam Med. 2008;6(4):331-339.
23. Orom H, Semalulu T, Underwood W III. The social and learning environments experienced by underrepresented minority medical students: a narrative review. Acad Med. 2013;88(11):17651777.

24. Kelchterman G. Who I am in how I teach is the message: self-understanding, vulnerability and reflection. Teachers Teach: Theor Pract. 2009;15(2):257-272.

25. Bell S. Self-reflection and vulnerability in action research: bringing forth new worlds in our learning. Syst Pract Action Res. 1998;11(2):179191. 